\title{
Technical and economical feasibility analysis of photovoltaic power installation on a university campus in indonesia
}

\author{
Ruben Bayu Kristiawan ${ }^{1, *}$, Indah Widiastuti ${ }^{1}$, and Suharno Suharno ${ }^{1}$ \\ ${ }^{1}$ Sebelas Maret University, Department of Mechanical Engineering Education, Surakarta, Indonesia
}

\begin{abstract}
Development of Renewable Energy System (RES) in Indonesia is an alternative solution for an increasing of fuel-based energy demand problem. Higher educational institutes may contribute to reducing the energy consumption by implementing green campus policies which include creating a medium-scale solar power installation. The research presents the feasibility analysis of photovoltaic power generation plants development in a university in the southern part of Java Island, Indonesia. In this article, different on/off-grid photovoltaic systems were considered in one of the campuses located in rural area. The technical viability of the proposed solar energy system is analyzed using HOMER software. The economic aspects of the plant are analyzed based on standard parameters, the NPC (Net Present Cost) and IRR (Internal Rate of Return) methods. The simulation studies are carried out to identify technical and cost-effective configuration. Feasibility study of the Photovoltaic energy generation was conducted by revealing their potential contributions and applicabilities. This study gives emphasis to the techno-economic analysis of renovating the energy supply system of a grid-connected large office building through an RES. Finally, results of the research can be used as the preference for the relevant stakeholders and policymakers in developing the grid-connected RES system.
\end{abstract}

\section{Introduction}

Higher education institutions like colleges and universities play an important role for society in driving the implementation of new technology. The green campus program provides significant contribution by promoting sustainable living to the society. Powering campus using renewable energy sources to replace or complement the traditional resources is part of efforts in protecting the environment. One of the examples is the use of solar energy sources to meet electricity demand at a campus in Indonesia [1]. However, currently, only a few universities in Indonesia implement the green campus program which only 57 universities among a total of 3225 universities. The list of Indonesian green campus is reported in Universitas Indonesia (UI) Green Metric World Ranking [2, 3].

Currently, most universities apply solar energy system partially such as for street or garden lighting. The system applied Off Grid system concerning relatively high investment costs $[4,5]$

Micro-grid/Photovoltaic power installation system has been a focus of several researchers intensively conducted across the world, including feasibility studies, computer modelling, control strategy and experimental work has been intensively conducted $[6,7]$. Meanwhile, the aim of this article provides an analysis of the possibility of micro-grid model installation that utilizes photovoltaic as a renewable energy source for an on-grid area at universities. These modelling of optimization is conducted using HOMER ${ }^{\circledR}$ software. The electricity usage, cost, and solar radiation data were required to perform techno-economic analysis based on sensitivities using HOMER simulations. To the best of author's knowledge, there is no comprehensive study on the HOMER based techno-economic analysis of such renewable energy systems at a campus area in the southern part of Java Island, Indonesia.

\section{Methodology}

The method used in this research is a case study using simulation considering of electricity demand and investment cost calculation of the installed power plant [8].

HOMER software has been applied to optimizing design and to measure the feasibility of the technoeconomic of the hybrid system. HOMER software is developed by National Renewable Energy Laboratory (NREL), USA. This software is suitable for optimal designing, sizing, and planning of hybrid renewable energy systems by performing analysis of technoeconomic of off-grid and grid-connected power systems. The configuration of the system can be optimized by minimizing the objective function of the constraints. The objective function in this analysis is the Net Present Cost (NPC) during the lifecycle cost of a component. The NPC is the present value of all the expenses of installing and running the component over the lifetime of the project, subtracted from the present value of all the

\footnotetext{
* Corresponding author: yabes.ruben@,student.uns.ac.id
} 
incomes over the project lifetime. The net present cost of each component in the system, and of the system as a whole is computed using HOMER. It makes energy balance for each hour and takes the electric or thermal loads per hour that a system can supply to demonstrate the configurations of the system [9]. Mostly, HOMER performs three steps to handle the feasibility analysis and optimization of the micro-grid systems before the installation: running simulations, performing sensitivity analysis and optimizing the simulated system. The electrical usage was inputted into the software interface and hybrid micro-grid system analysis was performed by using tools provided in the software. Loads, components and grid are the three main types of equipment of the hybrid renewable system. In this case, loads consist of the electric load and the components consist of PV, grid, batteries, and converters. HOMER modeled equipment's capacity was customized based on the requirement of the current system. Appropriate constraints were used for the sensitivity analysis build upon the system requirements for life cycle cost analysis. After these HOMER based analysis, post analysis was performed to produce a final decision by considering the cost market energy costs. The steps using HOMER are described in the fig.1 below.

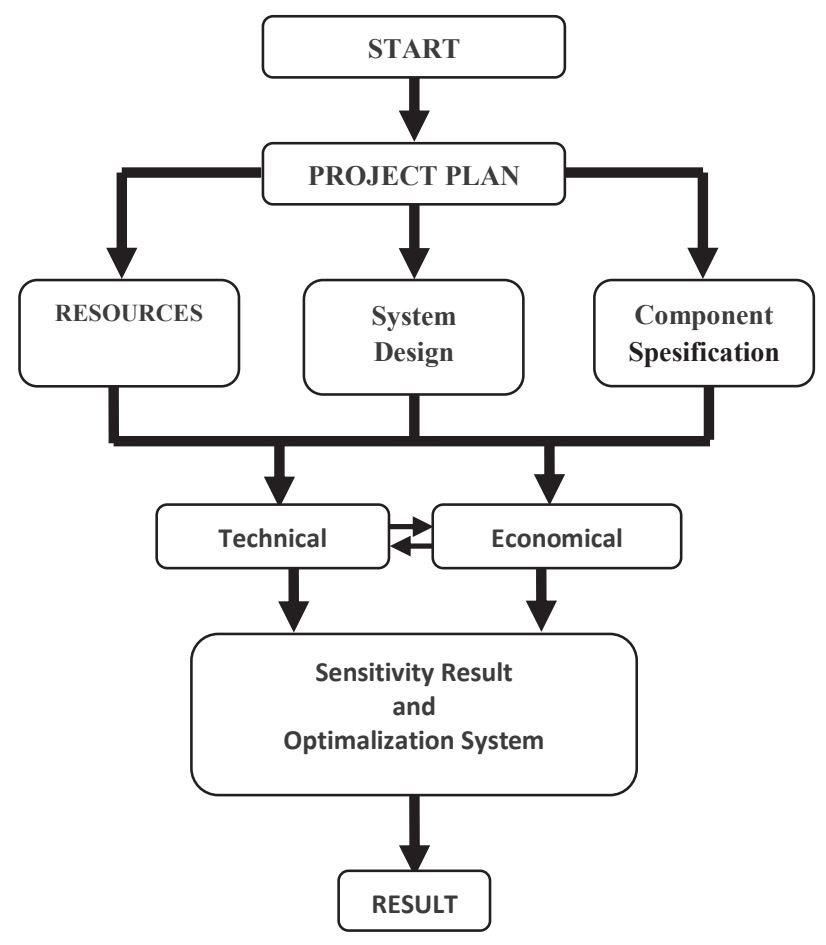

Fig. 1. HOMER steps.

\subsection{Study location and system configuration}

This study was conducted in one of Sebelas Maret University campuses, a university located in the southern part of Java Island, Indonesia. The campus area is located at $07^{\prime} 33^{\prime} .33^{\prime \prime} \mathrm{S} 110^{\prime} 46^{\prime} 27^{\prime \prime} \mathrm{E}$, with an altitude of 135 meters above sea level and the average of total rainfall per month is $325 \mathrm{~mm}$. Currently, the entire electricity demand of the campus is supplied by the utility grid through a distribution transformer. A simple micro-grid model proposed in this study is adjusted to the available local energy sources. Micro-grid is built using photovoltaic as renewable energy power plant, combined with the existing grid system. In this configuration, the installed PV power is used optimally. Along with that, the grid system also plays a role as the backup power source. The grid system will supply power when Photovoltaic system is unable to meet the needs of load and will absorb the excess power.

\subsection{Electric load profil}

The characteristics of electric load depend on the activities performed and equipment used. There are various campus activities such as lectures, exams, laboratory practice, research, final project, and administrative activities.. The equipments used consisting of lighting, air conditioning, water pump, computer, laboratory equipments, and workshop tools. The electrical usage was measured every hour for 24 hours. Furthermore, the electricity bill was also considered to represent the electricity usage. Afterward, those data are compared to be an input variable for HOMER. Daily and monthly load profiles can be seen in fig. 2. And fig. 3. It shows the difference loads every times, especially when there is not lecture activities.

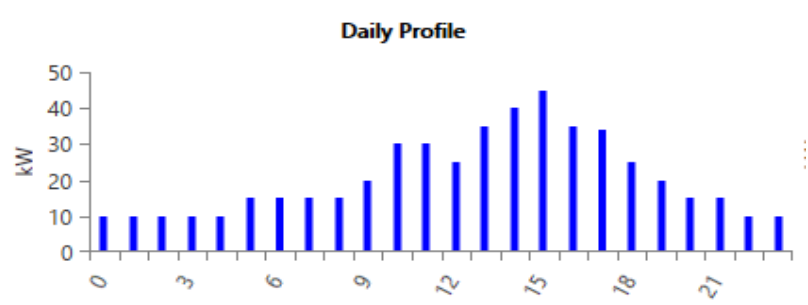

Fig. 2. Daily load profil.

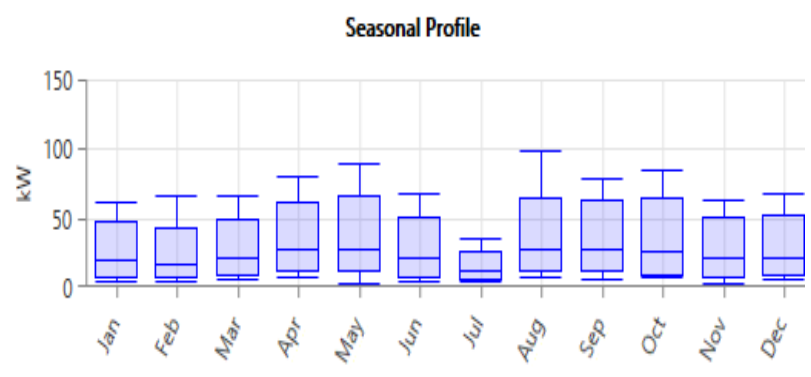

Fig. 3. Seasonal Load Profil.

\subsection{Solar energy resource}

Solar radiation data and Cleanness Index data are retrieved online from HOMER Energy Website, which is data set: NASA SSE World. Data latitude and longitude of the study location (07' 33'.33" S 110' 46' 27" E) and the time zone of location $(\mathrm{GMT}+07)$ are entered to the HOMER software. Scaled annual average of solar global horizontal irradiance (GHI) data obtained is shown 4.8 $\mathrm{kwh} / \mathrm{m}^{2} /$ day. 


\subsection{Solar module}

Trina Duomax PEG14 solar cell modules with capacity $320 \mathrm{Wp}$, efficiency $16.30 \%$, and made from monocrystalline were chosen in this research. These modules have usage life 25 years. The width of campus area which can be fully utilized for installing solar modules is $985 \mathrm{~m}^{2}$. The capacity of installed PV can be determined from the area. Using this following equation:

$$
\text { PV Area } x \text { PSI } x \eta_{p D}=P_{\text {peakpowey }}
$$

$$
985 \mathrm{~m}^{2} \times 1,000 \mathrm{~W} / \mathrm{m}^{2} \times 16.30 \%=160.55 \mathrm{KW}
$$

Where,

PSI : Peak Solar Insolation $\left(1,000 \mathrm{~W} / \mathrm{m}^{2}\right)$

$\eta_{p V}$ : Efficiency of PV module

By considering technical factor while installation process, the capacity of photovoltaic is $150 \mathrm{~kW}$ which requires an initial capital cost for procurement of solar panels USD $1088 / \mathrm{kW}$ and installation cost, the replacement cost of USD $915 / \mathrm{kW}$ and $1 \%$ operating \& maintenance cost of USD $11 / \mathrm{kW}$.

\subsection{Storage batteries}

The battery storage is required to improve the performance of micro-grid system. The battery is used to respond the short-time disturbances and variations of irradiation solar. The number and capacity of batteries per string is adjusted to the capacity and output voltage of PV generation. This hybrid system use 100 LeadAcid, $2 \mathrm{~V}$ batteries of $500 \mathrm{Ah}$. The capital cost and the replacement cost per battery are identified as the similar value USD 493.

\subsection{Inverter}

A inverter is used to convert the dc power obtained from solar panel to ac power. Usually, a inverter is rated according to the power of solar modules selected and the typical inverter efficiency, using this following equation:

$$
C_{\text {inverter }}=P_{\text {Array }} \times 100 / \eta_{\text {Inverter }}
$$

As, electricity consumption for the campus electricity purpose covering the maximum of the load curve is during the peak hours (7:00-19:00) and is being fulfilled by hybrid of the off-grid system. The main purpose of the hybrid system is to share the load during the peak hours, taking maximum from PV during the day and the rest is from grid and batteries. By considering the load sharing during the peak hours, a inverter of 153 $\mathrm{kW}$ capacity was selected for the PV array of $150 \mathrm{~kW}$ output. The efficiency of converter was considered to be $98 \%$ and the initial capital cost of the converter was assumed to USD $251 / \mathrm{kW}$.

\subsection{Utility grid}

The utility grid is the main power supplier, whereas the solar PV system runs in daytime only. However, if the power generated by the solar PV exceeds the primary load demand, the surplus electricity is sold to the grid. Several studies have shown that utilizing the excess energy in this way can significantly reduce the LCOE [10]. Currently, selling price of electricity from the grid system to the campus is IDR $900 / \mathrm{kWh}$ or USD $0.06 / \mathrm{kWh}$. Meanwhile, sellback price for excess power from power plants with renewable energy sources to grid system are regulated by the government, which is IDR $1,004 / \mathrm{kWh}$ or around USD $0.073 / \mathrm{kWh}$. It is stated in Regulation of the Minister of Energy, resource and minerals no 12 of 2012 [11].

\subsection{Analysis}

HOMER software is used to provide the system designers with feasibility and economic report of the system being designed, in order to check systems viability and the main purpose of the HOMER is to minimize the net present and operating costs of the system based on the sensitivity inputs. For the economic analysis, the annual discount rate of $8 \%, 25$ years project lifetime and the cost for each component based on market price was considered.

\section{Results and discussion}

The following are 4 major components of the system running. The components installed in the system can be seen in the table.1.

Table. 1. System architecture.

\begin{tabular}{|c|c|c|c|}
\hline Component & Name & Size & Unit \\
\hline PV & Trina Duomax PEG14 & 150 & KW \\
\hline Storage & ROLL Generic 500ah-2V & 100 & strings \\
\hline $\begin{array}{c}\text { System } \\
\text { Converter }\end{array}$ & Inverter & 153 & KW \\
\hline Grid & PLN & 177 & KW \\
\hline $\begin{array}{c}\text { Dispatch } \\
\text { strategy }\end{array}$ & HOMER Cycle Charging & & \\
\hline
\end{tabular}

The amount of electricity produced by the system in this study is $310.870 \mathrm{kWh} /$ year. Renewable energy fraction generates $70.1 \%$ or $218.045 \mathrm{kWh} /$ year, while the amount of electricity purchased from power utilities is $29.9 \%$.

The number energy consumed from total of production is $198,195 \mathrm{kWh} /$ year for satisfying electric load and the remaining $108.314 \mathrm{kWh} /$ year is sold to the grid. Schedule rate of grid is shown in fig.6 and fig.7. From these pictures below show the average purchase of electricity occurs at 18.00-21.00 and the average selling of electricity happens at 10.00-14.00. When the sunlight begins to disappear, the PV system incapable to supply enough electricity to fulfill electric load demand of the college at that time. 
The amount of monthly produced electricity can be seen in fig.8. This picture below shows the difference of

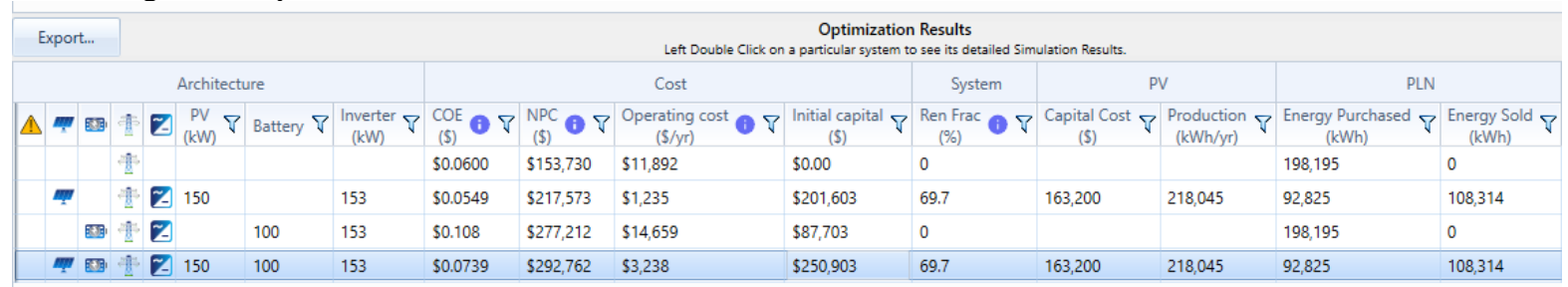

Fig. 4. Electricity optimization result $\$ 0.63 / \mathrm{kWh}$.

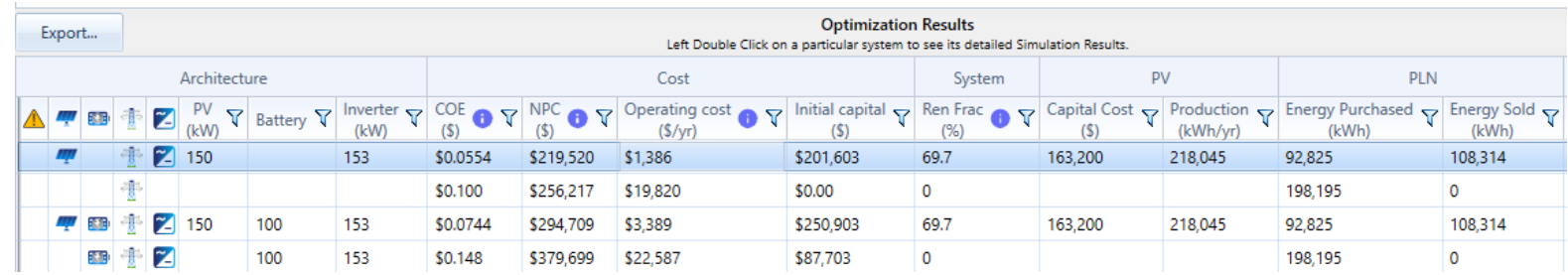

Fig. 5. Electricity optimization result $\$ 1 / \mathrm{kWh}$.

The capacity of PV system has been maximized as primary energy resource. The result of proposed system optimization can be seen in fig.4. The table in fig.4 shows 4 choices of system usage given by HOMER: grid usage, grid usage using battery storage, grid usage using PV without battery storage, and grid usage using PV with battery storage. These selections may be used to meet electricity needs of the college. This result has been sorted according to the numbers of NPC obtained from the running system.

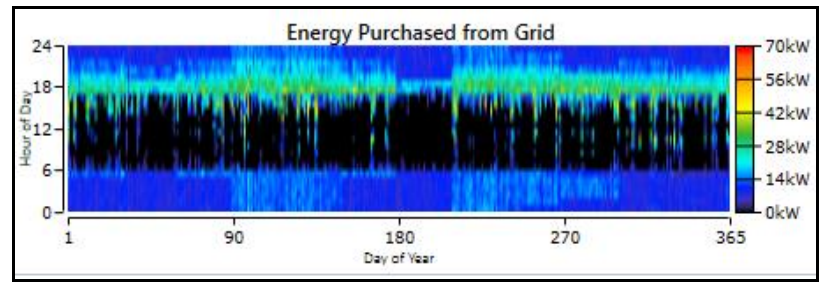

Fig. 6. Energy purchased from grid.

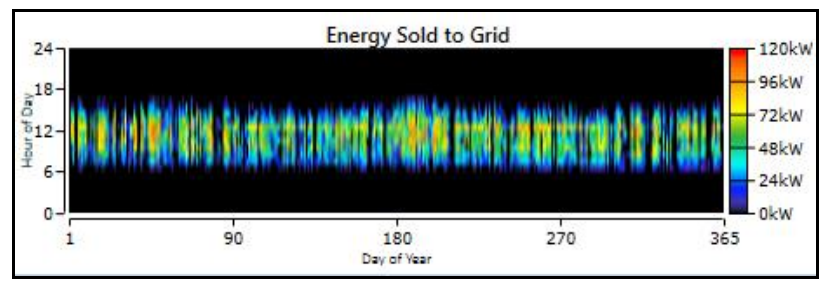

Fig. 7. Energy sold to grid.

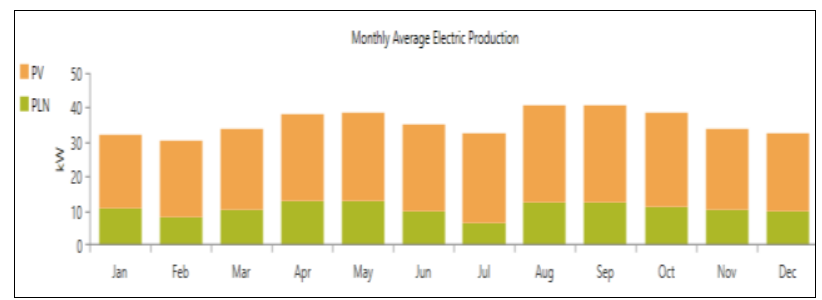

Fig. 8. Monthly Average Electric Production. electricity generation each month. 
Nazir (2013) find the NPC value of USD 337,641 for developing $5 \mathrm{~kW}$ capacity solar power generation system with battery storage at Andalas University, West Sumatera. Cost of purchasing electricity for that system is USD $0.824 / \mathrm{kWh}$. While Jongsun Lee (2016), in his research at New Haven Universities, Connecticut, discover the number of NPC value of USD -81,996 on development $67 \mathrm{~kW}$ capacity PV system. Its current electricity is USD $0.17 / \mathrm{kWh}$ with an estimated in an annual rising of electricity purchase prices of $3.5 \%$ and electric selling prices of USD $0.148 / \mathrm{kWh}$. The IRR value obtained from that project is $8.74 \%$ from the initial discount rate number of $6 \%[6,12]$. The research can show the effect of electricity purchase price on NPC or the present value of the developed system.

If the government revokes the subsidies from educational institutions, it will generate the different result. If we assume the cost of purchasing electricity from the grid is IDR $1,400 / \mathrm{kWh}$ or approximately USD $0.1 / \mathrm{kWh}$, HOMER will produce the result as seen in fig.5. That picture indicates the cost of purchasing electricity USD $0.1 / \mathrm{kWh}$, thus the system had the lowest NPC cost is PV system without battery storage, with the amount of total NPC, is equal to USD 219,520.

\section{Conclusions}

Technically the utilization of PV systems on campus can be feasible because, of the $985^{\mathrm{m}^{2}}$ campus area that can be utilized for PV systems and local resources, including solar radiation and the availability of PV components can meet the needs of electric load on campus. In addition, the utilization of PV systems can implement green campus policies.

However, economically, utilize of photovoltaic at the colleges or universities nowadays is considered unfeasible because the high value of NPC which is USD 292,762 exceeded NPC's value of using electricity from the power utility grid. Another parameter also calculated is IRR value, which has value less than discount rate value of $4.9 \%$ from discount rate value of $8 \%$. The system categorized reasonable to be proposed by HOMER software is electricity usage from power utility grid. The number of total NPC of this system is USD 153,730 . That is because of the government still subsidies the electricity cost to the educational institutions.

Currently, colleges or universities are able to play role in renewable energy utilization. Stakeholders can choose the sources of energy needed by their college. Later, if the government changes the regulation related to the subsidy of the electricity price by reducing the subsidy or revoking it completely, the application of Photovoltaic power generation system can be considered.

The authors thank to the Institute of Research and Community Service Sebelas Maret University for the research grant provided.

\section{References}

1. S. Erni, Green Life, Green Campus (Kajian Pemahaman Kehidupan Hijau di Lingkungan Akademisi Universitas Islam Negeri Sultan Syarif Kasim Riau (2013)

2. U. Green Metric, List of Universities in Each Country (2017) (UI GreenMetric World Univ. Rank., 2017)

3. BPS, "Jumlah Perguruan Tinggi, Mahasiswa, dan Tenaga Edukatif (Negeri dan Swasta) di Bawah Kementrian Pendidikan dan Kebudayaan Menurut Provinsi tahun ajaran 2013/2014-2014/2015," Bps (2015)

4. D. Kurniati, T. Lilo, E.S. Murtiono, Studi Implementasi Green Building Di Universitas Sebelas Maret Surakarta (2013)

5. I.D. Hapsari, N. Sumarjiyanto BM, E.Y. Purwanti, "Perencanaan Dan Penganggaran Kampus Berkelanjutan: Green Campus Universitas Diponegoro," Teknik, 35 (2), 86-93 (2014)

6. R. Nazir, H.D. Laksono, E.P. Waldi, E. Ekaputra, P. Coveria, "Renewable energy sources optimization: A micro-grid model design," Energy Procedia, 52, 316-327 (2014)

7. M.H. Nehrir et al. "A review of hybrid renewable/alternative energy systems for electric power generation: Configurations, control, and applications," IEEE Trans. Sustain. Energy, 2 (4), 392-403 (2011)

8. J.L. Bernal-Agustın, R. Dufo-Lopez, D.M. RivasAscaso, "Design of isolated hybrid systems minimizing costs and pollutant emissions," Renew. Energy, 44, 215-224 (2012)

9. M.K. Shahzad, A. Zahid, T. Rashid, M.A. Rehan, M. Ali, M. Ahmad, "Techno-economic feasibility analysis of a solar-biomass off grid system for the electrification of remote rural areas in Pakistan using HOMER software," Renew. Energy, 106, 264-273 (2017)

10. H.Z. Al Garni, A. Awasthi, M.A.M. Ramli, "Optimal design and analysis of grid-connected photovoltaic under different tracking systems using HOMER," Energy Convers. Manag., 155, 42-57 (2018)

11. H. Patricia, "Analisis Keekonomian Kompleks Perumahan Berbasis Energi Sel Surya (Studi Kasus : Perumahan Cyber Orchid Town Houses, Depok)," p. 83 (2012)

12. J. Lee, B. Chang, C. Aktas, R. Gorthala, "Economic feasibility of campus-wide photovoltaic systems in New England,” Renew. Energy, 99, 452-464 (2016) 